\title{
Hubungan antara Self-control dan Dukungan Sosial terhadap Agresivitas Remaja
}

\author{
ALIFTRA ALWI \& ILHAM NUR ALFIAN* \\ Departemen Psikologi Kepribadian dan Sosial, Fakultas Psikologi Universitas Airlangga
}

\begin{abstract}
ABSTRAK
Penelitian ini bertujuan untuk mengetahui bagaimana prediktor dalam self-control dan dukungan sosial mampu memprediksi agresivitas pada remaja di kota Surabaya. Responden dalam penelitian ini adalah remaja yang bersekolah di surabaya dengan rentang usia 12-21 tahun. Jumlah sample dalam penelitian ini sebanyak 118 orang, meliputi 31 remaja laki-laki dan 87 remaja perempuan. Teknik pengumpulan data pada penelitian ini adalah survei, menggunakan kuesioner. Variabel self-control dalam penelitian ini diukur menggunakan self-control, sedangkan dukungan sosial menggunakan ISEL (Interpersonal Support Evaluation List), serta agresivitas menggunakan aggression scale. Analisis data yang digunakan adalah stepwise regression dengan menggunakan SPSS Versi 25.0 for windows. Berdasarkan hasil analisis data penelitian, menunjukan bahwa self-control dan dukungan sosial mampu memprediksi agresivitas dengan nilai $(B=-0,509, p=0,000)$ dan $R^{2}=0,259$, self-control mampu memprediksi agresivitas dengan nilai $(B=-0,437, p=0,000)$, dan dukungan sosial mampu memprediksi agresivitas dengan nilai $(B=-$ $0,326, \mathrm{p}=0,000)$.
\end{abstract}

Kata kunci: agresivitas, dukungan sosial, kontrol diri, remaja

\section{ABSTRACT}

This study conducted to find out how the self-control and social support could be used to predict aggressivity on adolescents in Surabaya. The participantsin this study were 12-21 years old adolescents that goes to schools in Surabaya. The participants were of 31 male and 87 female who filled out the survey using the questionnaire method. The self-control variable was measured using the self-control scale, the social support variable was measured using ISEL (Interpersonal Support Evaluation List), the aggressivity variable was measured using aggression scale. Data analysis was done through stepwise regression using SPSS 25.0 for windows. According to data analysis results, showed that self-control and social support can be used to predict aggressivity with $(B=-1,938, p=0,010)$ and $R^{2}=0,296$, self-control could predict the aggressivity with $(B=-0,437, p=0,000)$, and social support could also predict aggressivity $(B=-0,326, p=0,000)$.

Keywords: adolescent, aggression, self-control, social-support

Buletin Penelitian Psikologi dan Kesehatan Mental (BRPKM), 2021, Vol. 1(1), 338-346

*Alamat korespondensi: Fakultas Psikologi Universitas Airlangga, Kampus B Universitas Airlangga Jalan Airlangga 4-6 Surabaya 60286. Surel: ilham.nuralfian@psikologi.unair.ac.id

Naskah ini merupakan naskah dengan akses terbuka dibawah ketentuan the Creative Common Attribution License (CC-BY-4.0) (http://creativecommons.org/licenses/by/4.0), 
sehingga penggunaan, distribusi, reproduksi dalam media apapun atas artikel ini tidak dibatasi, selama sumber aslinya disitir dengan baik.

\section{PE N D A H U L U A N}

Remaja merupakan fase awal dari masa produktif manusia (Hurlock, 2001). Masa remaja merupakan peralihan dari masa anak-anak menuju masa dewasa dengan rentang usia antara 12-22 tahun, dimana rata-rata setiap remaja pada masa ini memasuki usia sekolah menengah dan terjadi proses pematangan baik itu pematangan fisik, psikologis maupun sosialnya. Masa remaja dapat dibilang merupakan usia yang bermasalah, masa remaja sering menjadi masalah yang sulit diatasi baik oleh anak laki-laki maupun perempuan. Perbedaan karakteristik dan ketidakmampuan mereka untuk mengatasi sendiri masalahnya menurut cara yang mereka yakini, banyak remaja akhirnya menemukan bahwa penyelesaiannya tidak selalu sesuai dengan harapan mereka (Hurlock, 2001).

Remaja memiliki tugas-tugas perkembangan yang harus dicapai seperti membangun interaksi dengan lingkungan, keluarga, serta teman sebaya (Hurlock, 2001). Pada saat ini dalam suatu kelompok teman sebaya terdiri dari remaja dengan banyak perbedaan. Perbedaan tersebut antara lain, faktor budaya, bawaan, kebiasaan keluarga dan proses sosialisasi yang dialami oleh remaja. Karakteristik yang unik akibat dari perpindahan pada masa anak- anak menuju masa dewasa antara tiap remaja dan remaja lainnya yang tidak sama inilah seringkali menimbulkan masalah, seperti pertengkaran sesama teman, antar kelompok, mengkonsumsi alkohol, serta kenakalan remaja lainnya (Hurlock, 2001). Konflik antar teman sebaya tidak bisa dipungkiri seringkali terjadi karena adanya perbedaan-perbedaan tersebut (Santrock, 1995). Remaja cenderung bergabung dan berinteraksi dengan kelompok sosialnya untuk mengembangkan keterampilan-keterampilan sosialnya. Adanya interaksi tersebut menyebabkan remaja juga mengalami konflik dalam hubungannya dengan orang lain (Monks, F., Knoers, A., \& Hadito, 1999). Remaja sangat rentan berperilaku agresif karena mereka berada dalam proses mencari jati diri dan belum bisa mengendalikan luapan emosi sebagai reaksi terhadap kegagalan (Hurlock, 2001). Dampak dari luapan emosi tersebut bisa menjadi pemicu timbulnya perilaku agresi.

Dalam data DP5A tahun 2018 terdapat 184 kasus kekerasan baik fisik, psikis maupun seksual, tahun 2019 terdapat 195 kasus serta tahun 2020 per bulan juni terdapat 78 kasus. Pada bulan agustus 2019 terdapat video viral yaitu sang anak tega memukul kepala ibunya dikarenakan sang anak meminta uang tetapi tidak dikasih oleh ibunya (Nurhalim, 2019).

Perilaku agresif juga beberapa kali terjadi di Surabaya, salah satunya terjadi di Rungkut. Kanit reskrim polsek rungkut mediasi perkelahian remaja yang berinisial NN (18), AM (18), JA (15), AW (15), dan KL (15). pada tanggal 19 Januari 2020 sekitar pukul 02.00 WIB yang berlokasi di Medokan Ayu saat itu korban sedang berteduh selanjutnya melintas 3 remaja mengendarai sepeda motor dan menegur korban yang dianggap menantang pelaku lalu terjadi pemukulan yang dilakukan pelaku kepada korban, NN mencoba melawan pelaku namunsalah satu korban lainnya mencoba melerai tetapi terkena pecahan botol kaca yang mengenai lengannya dan pelaku melarikan diri (polsekrungkut, 2020).

Usia remaja seharusnya diisi dengan prestasi, bukan aksi kekerasan yang nyata. Remaja sangat rentan berperilaku agresif karena mereka berada dalam proses mencari jati diri dan belum bisa mengendalikan luapan emosi sebagai reaksi terhadap kegagalan (Hurlock, 2001). Dampak dari luapan emosi tersebut bisa menjadi pemicu timbulnya perilaku agresi.Menurut Suryanto, dkk. (2012) agresivitas ialah perilaku yang mengarah pada melukai seseorang secara di sengaja, merusak sesuatu, membunuh, menghina secara verbal, memukul dalam keadaan emosi yang tidak stabil atau marah. Perilaku agresif yang 
dilakukan oleh remaja merupakan masalah yang dari dulu sampai sekarang tidak pernah ada penyelesaian untuk menghentikan kasus kekerasan yang terjadi di kalangan remaja maupun pelajar. Agresi dapat diartikan sebagai perilaku atau kecenderungan perilaku yang diminati untuk menyakiti orang lain, baik secara fisik maupun psikologis. mendefinisikan agresi sebagai respon yang memberikan rangsangan berbahaya ke organisme lain (Buss \& Perry, 1992).

Faktor-faktor penyebab terjadinya perilaku agresi tersebut antara lain emosi yang tidak terkontrol, harga diri yang terusik, pengalaman tidak menyenangkan, pengaruh kelompok teman sebaya, ingin mendapat perhatian lebih, kurangnya rasa percaya dari orang disekitarnya, serta adanya provokasi dari pihak lain diluar kelompoknya. Remaja menjadi agresi dikarenakan kontrol diri yang rendah (Zahrani \& Ambarini, 2019). Selain itu ada faktor eksternal seperti dukungan sosial.

Remaja yang agresif memiliki nilai toleransi yang rendah terhadap frustrasi, cenderung berekasi terhadap dorongan agresinya dan kurang dapat bertanggung jawab atas akibat perbuatannya (Knort, et al., 2007 dalam Sumijah, 2016), seperti dengan gangguan mood, agresi juga sudah ditandai dengan impulsif, permusuhan, kemarahan serta ketakutan (Atkins \& Stoff, 1993 dalam Sumijah, 2016)). Gangguan mood termasuk dalam kecemasan dan depresi yang dikaitkan dengan agresi (Christie, 2007).

Menurut House (dalam Ratnasari, 2017) menjelaskan dukungan sosial adalah seberapa besar fungsi dari hubungan yang dapat dikategorikan dalam empat aspek yaitu dukungan emosional, dukungan instrumental, dukungan informasi dan dukungan penilaian. Dukungan sosial merupakan sebuah istilah yang merujuk pada sumber daya sosial yang dianggap tersedia atau yang sebenarnya diberikan kepada mereka dari non-profesional maupun profesional dalam konteks grup dukungan formal dan hubungan informal (Cohen, L.G Underwood; Gottlieb, 2000). Aksüllü (2004, dalam Õ, 2010). yang mendefinisikan dukungan sosial sebagai bantuan fisik dan psikologis kepada individu dalam situasi khusus, dan juga menyediakan kebutuhan sosial dasar individu seperti cinta, kesetiaan, harga diri dan rasa menjadi bagian dari kelompok.

Menurut Hoberman (1983) terdapat empat komponen dukungan sosial yaitu, belonging support ialah dukungan dengan menghabiskan waktu bersama dengan orang lain untuk bersenang-senang, selfesteem support dukungan yang dalam bentuk pemberian inspirasi, semangan, serta memberikan esensi sesuatu hal, tangiable support ialah seseorang dapat membantu mengurangi stress dengan memberikan solusi secara nyata dari masalah yang sedang dihadapi, appraisal support ialah dukungan sosial yang berupa penilaian atau ketersediaan seseorang untuk membicarakan suatu masalah yang diahadapi. Remaja dalam contoh kasus ialah minimnya tangiable support yang diterima sehingga remaja mengalami frustrasi atau stres yang menyebabkan timbulnya agresivitas, tangiable support merupakan komponen dukungan sosial. Dukungan lingkungan sangat dibutuhkan dalam proses penyesuaian diri remaja dengan lingkungan.

Remaja yang melakukan perilaku agresif dapat dikarenakan kontrol diri yang dimiliki cenderung rendah (Zahrani \& Ambarini, 2019). Menurut Averill (dalam Marsela \& Supriatna, 2019) kontrol diri adalah kemampuan individu dalam mengelola informasi yang diinginkan dan yang tidak diinginkan, serta kemampuan individu untuk memilih salah satu perilaku yang berdasarkan atas ia yakini. Self-control adalah kemampuan individu untuk berperilaku yang tenang dan tidak meledak-ledak, dapat memikirkan resiko dari perilakunya, berusaha mencari informasi sebelum megambil keputusan, tidak mengandalkan kekuatan fisik dalam menyelesaikan masalah dan tidak bersikap egois atau mudah marah (Praptiani, 2013). 
Untuk mengendalikan emosi diperlukan kontrol diri yang sangat baik bagi remaja (Luthfi, 2009). Dalam beberapa kasus, remaja mempunyai kontrol diri yang rendah sehingga tidak dapat mengendalikan emosi dengan sangat baik Kurangnya kemampuan kontrol diri untuk mengendalikan rasa marah pada remaja menyebabkan munculnya perilaku melawan (Orpinas \& Frankowski, 2001) dan persepsi ancaman yang mereka rasakan menimbulkan rasa dendam dan dorongan untuk membalasnya dengan perilaku yang agresi (DeWall et al., 2011).

Menurut Ghufron (2010 dalam Marsela \& Supriatna, 2019) faktor-faktor yang dapat mempengaruhi kontrol diri yaitu faktor internal dan faktor eksternal. Faktor internal yang berperan dalam kontrol diri antara lain usia, cara pola asuh orang tua, sedangkan faktor eksternal antara lain lingkungan dan keluarga. Tinggi rendahnya agresivitas remaja dipengaruhi oleh kontrol diri, dimana remaja yang memiliki kontrol diri tinggi maka agresivitasnya rendah sedangkan remaja yang memiliki kontrol diri rendah maka agresivitasnya tinggi (Praptiani, 2013).

Sudah ada beberapa penelitian terkait self-control dan agresivitas. Beberapa penelitian yang dilakukan sebelumnya menyatakan bahwa self-control merupakan prediktor dari perilaku agresi (DeWall et al., 2011). Apabila individu gagal memiliki self-control, maka besar kemungkinan bahwa individu akan melakukan perilaku agresi. Penelitian yang dilakukan (Denson et al., 2012) menyatakan bahwa apabila individu memiliki dorongan untuk berbuat perilaku agresi, kontrol diri juga dapat membantu individu untuk meredam keinginan untuk melakukan perilaku agresif. Hal ini juga didukung oleh penelitian sebelumnya yang dilakukan oleh Zahrani \& Ambarini (2019) serta penelitian yang dilakukan oleh DeWall, dkk. (2011), penelitian tersebut menyatakan bahwa adanya kontrol kognitif pada self-control dapat mengurangi tingkat agresi seseorang dan dapat membantu mekanisme neural otak dalam meregulasi emosi. Lalu ada pula beberapa penelitian terkait dukungan sosial dan agresivitas. Penelitian yang dilakukan oleh Sumijah (2016) dan Grandis (2019) menyatakan bahwa individu yang memiliki dukungan sosial yang tinggi, maka akan menurunkan agresivitas remaja. Remaja yang memiliki dukungan sosial akan memiliki kesehatan mental yang baik, sehingga remaja memiliki perilaku yang bermoral, tidak egois, saling menghargai, percaya diri, terpenuhinya kebutuhan rasa aman, serta dapat bersosialisasi dengan baik di lingkungan sekitarnya. Frustrasi terjadi karena keinginan akan kebutuhannya tidak tercapai, kondisi ini berpeluang untuk.

Meskipun beberapa penelitian sudah dilakukan, penelitian yang meneliti dukungan sosial dan selfcontrol terhadap agresivitas remaja cenderung masih sedikit. Hal ini yang menjadi pertimbangan penulis untuk melakukan penelitian terkait hubungan antara self-control dan dukungan sosial terhadap agresivitas remaja. Sehingga penelitian ini memiliki tiga hipotesis, yaitu $\mathrm{H}_{1}=$ Self-control mampu memprediksi secara signifikan terhadap kemunculan agresivitas, $\mathrm{H}_{2}=$ Dukungan sosial mampu memprediksi secara signifikan terhadap kemunculan agresivitas, lalu $\mathrm{H}_{3}=$ Self-control dan dukungan sosial secara simultan dapat memprediksi secara signifikan terhadap kemunculan agresivitas.

\section{Desain Penelitian}

\section{E T O D E}

Metode penelitian yang digunakan pada penelitian ini adalah kuantitatif-eksplanatori dengan metode data survei. Penelitian ini dilakukan dalam dimensi waktu cross-sectional. Variabel terikat dalam penelitian ini adalah agresivitas, dan variabel bebas dalam penelitian ini adalah self-control serta dukungan sosial. 


\section{Partisipan}

Partisipan dalam penelitian ini adalah remaja yang berdomisili di Kota Surabaya yang berusia 12-21 tahun yang juga merupakan siswa SMP/SMA di Surabaya. Jumlah partisipan dalam penelitian ini adalah $118\left(\mathrm{M}_{\text {usia }}=15,03 ; \mathrm{SD}_{\text {usia }}=1,912\right)$ dengan paling banyak kelompok usia partisipan adalah usia 17 tahun (27\%) dan perempuan $(73,73 \%)$

Teknik sampling yang digunakan dalam penelitian ini adalah teknik purposive sampling karena penelitian ini membutuhkan kriteria-kriteria tertentu dalam pencarian subjek agar hasil penelitian sesuai dengan tujuan penelitian. Sebelum partisipan mengisi survei, partisipan diminta untuk menyetujui informed consent, sehingga partisipan yang sudah mengisi survei merupakan individu yang menyetujui untuk mengisi survei yang ada. Dalam penentuan jumlah sampel, penulis menggunakan rumus perspektif Tabachnick dan Fidell dalam (Pallant, 2010)Perhitungan ini mendapatkan hasil sampel yang dibutuhkan dalam penelitian ini yaitu sebanyak $\mathrm{N}=66$.

\section{Pengukuran}

Penelitian ini menggunakan alat ukur the Aggression Questionnaire yang dibuat oleh Buss dan Perry (1992) yang sudah ditranslasi ke dalam Bahasa Indonesia untuk variabel agresivitas. Alat ukur ini merupakan alat ukur yang berbentuk kuesioner self-report yang terdiri dari 29 item yang disusun oleh pengarangnya dengan menggunakan aspek-aspek anger (7 item), verbal aggression (5 item), physical aggression (9 item), dan hostility (8 item). Alat ukur agresivitas ini memiliki 5 pilihan jawaban (1='Sangat tidak sesuai', 5='Sangat sesuai'). Alat ukur agresivitas ini memiliki reliabilitas yang baik $(\alpha$ $=0,887$ ).

Variabel self-control dalam penelitian ini menggunakan alat ukur yang dibuat oleh penulis. Alat ukur ini merupakan alat ukur yang berbentuk kuesioner self-report yang terdiri dari 36 item dengan menggunakan aspek-aspek self-discipline (9 item), deliberated (10 item), healthy habits (7 item), work ethic (5 item), dan reliability (5 item). Alat ukur self-control ini memiliki 4 pilihan jawaban (1='Sangat tidak setuju, $4=$ Sangat setuju'). Alat ukur self-control ini memiliki reliabilitas alat ukur yang baik $(\alpha=0,835)$.

Variabel dukungan sosial dalam penelitian ini menggunakan alat ukur ISEL (Interpersonal Support Evaluation List) yang dibuat oleh (Cohen, S; Hobermen, 1983) yang sudah ditranslasi ke dalam Bahasa Indonesia dan diadaptasi oleh (Wulandari, 2016). Alat ukur ini merupakan alat ukur yang berbentuk kuesioner self-report yang terdiri dari 48 item dengan menggunakan aspek-aspek tangiable support (10 item), belonging support (10 item), self-esteem support (10 item), appraisal support (10 item). Alat ukur ISEL ini memiliki 4 pilihan jawaban (1='Sangat tidak setuju, $4=$ Sangat setuju'). Alat ISEL dalam penelitian ini memiliki reliabilitas yang baik $(\alpha=0,888)$.

Pembuktian hipotesis dalam penelitian ini menggunakan uji analisis analisis regresi berganda. Sebelum melakukan analisis data, penulis melakukan uji asumsi yang termasuk di dalamnya uji normalitas, dan uji linearitas, uji heterokedesitas, uji multikolinearitas, dan juga dilakukan uji korelasi untuk memperkuat bahwa terdapat hubungan, dan juga menjadi syarat untuk melakukan analisis dengan metode regresi. Metode regresi menggunakan metode stepwise regression sehingga dapat diketahui penambahan nilai $\mathrm{R}$ dan $\mathrm{R}^{2}$ ketika menambahkan variabel prediktor lainnya. 


\section{Analisis Data}

Uji korelasi dan uji regresi yang diakukan dalam penelitian ini menggunakan software IBM SPSS Statistic 25 for Windows. Uji analisis stepwise reggression digunakan untuk mengetahui peningkatan variabel apabila menambahkan variabel bebas lainnya (Fields, 2018).

\section{HAS I L P EN EL I T I A N}

Hasil uji analisis korelasi menunjukan bahwa variabel self-control terdapat hubungan negatif dan cenderung sedang $(r(118)=-0,437 ; p<0,000)$ terhadap agresivitas. Uji korelasi juga menunjukan bahwa variabel dukungan sosial terdapat hubungan negatif dan cenderung sedang $(r(118)=-0,326 ; p<0,000)$ terhadap agresivitas. Lalu hasil uji regresi menunjukkan bahwa terdapat adanya pengaruh signifikan dari self-control terhadap agresivitas remaja sebesar 19,1\%, $\left(r^{2}=0,191 ; p=0,000\right)$. Uji regresi juga dilakukan pada kedua variabel terhadap agresivitas remaja yang menghasilkan kedua variabel tersebut memiliki pengaruh signifikan terhadap agresivitas remaja $\left(\mathrm{r}^{2}=25,9 \% ; \mathrm{p}=0,000\right)$. Lalu uji korelasi antara variabel dukungan sosial terhadap perilaku agrevisitas remaja $(\beta=-0,264 ; p=0,002)$ menunjukan bahwa Dukungan sosial mampu memprediksi secara signifikan terhadap kemunculan agresivitas. Dalam penelitian ini, variabel self-control $(B=-0,612 ; S E=0,126 ; t=-4,870 ; p=0,000 ; \beta=-0,396)$ dan variabel dukungan sosial $(B=-0,303 ; S E=0,093 ; t=-3,245 ; \mathrm{p}=0,002 ; \beta=-0,264)$ menghasilkan garis regresi $\left(\mathrm{Y}^{\prime}=\right.$ 176,477 - 0,612 self-control - 0,303 dukungan sosial).

\section{I S K U S I}

Hasil pada penelitian ini self-control berkorelasi negatif dengan agresivitas remaja, dengan nilai koefisien korelasi sebesar -0,437 yang bisa dikatakan mempunyai hubungan moderated dimana taraf signifikan atau $\mathrm{p}=0,000$ yang memiliki nilai lebih kecil dari 0,05. Serta dalam uji regresi mempunyai taraf signifikansi sebesar 0,000 dan nilai koefisien $R^{2}$ sebesar 0,191 yang menyatakan bahwa ada variabel self-control menjadi prediktor terhadap agresivitas sebesar 19,1\%. Hal itu dapat diartikan bahwa selfcontrol dapat memprediksi agresivitas sebesar 19,1\% dan 80,9\% diprediksi oleh variabel lainnya.

Dari hasil penelitian tersebut mendukung penelitian sebelumnya yang pernah dilakukan oleh DeWall et al. (2011) dan Praptiani (2013) yang menyatakan bahwa rendahnya self-control merupakan prediktor cukup penting dari agresivitas, serta faktor-faktor yang dapat menurunkan self-control akan meningkatkan agresivitas, sedangkan faktor yang dapat memperkuat tingkat self- control seharusnya dapat menurunkan tingkat agresivitas. Individu yang mampu memahami mengenai self-control akan lebih dapat mengontrol dirinya sendiri sehingga dapat memilih atau menyikapi dengan hal yang positif. Dorongan untuk berbuat menyimpang seperti kenakalan, perkelahian, maupun agresi yang sedang mencapai puncaknya, self-control dapat membantu individu tersebut untuk menurunkan agresivitas dengan mempertimbangkan norma sosial serta aturan yang berada di lingkungannya.

Hasil analisis data dalam penelitian ini menggunakan teknik analisis regresi linier berganda, dengan signifikansi atau $\mathrm{p}=0,000$ yang memiliki nilai lebih kecil dari 0,05 . Menyatakan bahwa variabel selfcontrol dan dukungan sosial secara bersama-sama menjadi prediktor agresivitas. Dengan korelasi sebesar 0,509 dimana nilai tersebut tergolong tinggi, sedangkan $\mathrm{R}^{2}$ sebesar 0,259 , yang menyatakan bahwa variabel self-control dan dukungan sosial dapat memprediksi secara simultan terhadap agresivitas sebesar 25,9\%, sedangkan 74,1\% diprediksi oleh variabel lainnya.

Sejalan dengan penelitian Hamama \& Ronen-shenhav (2012) yang menyatakan terdapat korelasi negatif antara kontrol diri dan dukungan sosial terhadap agresivitas remaja yang memiliki keluarga utuh

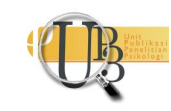


ataupun keluarga bercerai. Ketika seseorang memiliki dukungan yang tersedia bagi individu tersebut, dapat menekan muncuknya ancaman yang berasal dari peristiwa tersebut, dan mampu memecahkan masalah dengan hal yang positif. dikarenakan dukungan sosial dapat mencegah penilaian suatu peristiwa yang dianggap menjadi stres dan ikut melibatkan orang disekitar, orang tua, teman, dan guru (Wills, 1985).

Hasil dari uji analisis sebelumnya mendapatkan hasil bahwa dukungan sosial juga merupakan prediktor agresivitas, dengan dibuktikan hasil F hitung sebesar 13,770 dengan $\mathrm{p}=0,000$ lebih kecil dari 0,05. Serta $\mathrm{R}$ (korelasi) terhadap agresivitas sebesar-0,326 masuk dalam kategori moderated, dan $R^{2}=0,106$. Yang artinya dukungan sosial menjadi prediktor variabel agresivitas sebesar 10,6\%, dan 79,4\% di prediksi oleh variabel lainnya. Hasil ini mendukung penelitian Grandis (2019) yang menyatakan bahwa pemberian dukungan instrumental, dukungan informasi, dukungan emosional dan dukungan penilaian positif yang didapat seorang remaja dari teman sebaya dapat menurunkan agresivitas remaja. Bertolak belakang dengan hasil Prayogo (2018) yang menyatakan bahwa tidak ada hubungan secara parsial antara dukungan sosial terhadap agresivitas. Dalam masa remaja memerlukan bantuan atau dukungan dari orang tua, teman, guru maupun orang yang berada di sekitarnya, dapat ditunjukkan bahwa dalam kategorisasi dukungan sosial cenderung sedang yang paling tinggi.

\section{S I M P U L A N}

Setelah dilakuannya pengujian hipotesis beserta pembahasan dalam penelitian ini, dapat disimpulan bahwa self-control dapat memprediksi kemunculan agresivitas secara signifikan. Lalu dukungan sosial dapat memprediksi kemunculan agresivitas secara signifikan. Serta self-control dan dukungan sosial dapat memprediksi kemunculan agresivitas secara signifikan. Hal ini menunjukkan bahwa variansi agresivitas dapat dijelaskan oleh kedua variabel bebas secara parsial maupun simultan.

Saran dari penelitian ini bagi peneliti selanjutnya adalah diharapkan peneliti selanjutnya juga mempertimbangkan faktor lain yang menjadi prediktor agresivitas pada remaja di Surabaya diluar variabel yang ada di penelitian ini. Selain itu, dapat dilakukan pula pengambilan data sekunder dari pada SO (significan others) pada guru sekolah agar mendapatkan informasi lebih lanjut perilaku subjek di sekolah, supaya dapat menggambarkan remaja yang sebenarnya. Peneliti mengambil langkah untuk pengambilan data melalui kuesioner online, karena terdapat musibah dari wabah virus Covid-19. Adapula saran untuk masyarakat terutama remaja, diharapkan dapat meningkatkan self- control mereka melalui penyesuaian norma atau nilai yang akan diterapkan oleh orang tua dan kelompok (komunitas) sebagai wujud dukungan sosial.

\section{U C AP A N T ERIMAKAS IH}

Saya ucapkan terima kasih kepada Tuhan Yang Maha Esa, keluarga, dan seluruh teman-teman yang tidak henti-hentinya mendukung dan menyemangati saya selama penelitian ini berlangsung hingga selesai. Serta, terima kasih kepada peneliti terdahulu yang sudah memberikan saya alat ukur dan izin untuk menggunakannya sehingga memudahkan proses penelitian ini. 


\section{DEKLARAS I POTENSI TERJADINYA KONFLIK KEPENTINGAN}

Aliftra Alwi Hidayah Tulloh dan Ilham Nur Alfian tidak bekerja, menjadi konsultan, memiliki saham, atau menerima dana dari perusahaan atau organisasi manapun yang mungkin akan mengambil untung dari diterbitkannya naskah ini.

\section{PUST AKA ACUAN}

Fields, A. (2018). DISCOVERING STATISTICS USING IBM SPSS STATISTICS (5 $5^{\text {th }}$ ed). SAGE Publications Inc.

Buss, A. H., \& Perry, M. (1992). PERSONALITY PROCESSES AND INDIVIDUAL The Aggression Questionnaire. 63(3), 452-459.

Christie, S. (2007). Current Approaches to the Assessment and Management of Anger and Aggression in Youth : A Review.

Cohen, S; Hobermen, H. (1983). Positive events and social supports as buffers of life change stress. Journal of Appleid Psychology.

Cohen , L.G Underwood; Gottlieb, H. b. (2000). Social Support Measurement and Intervention. Oxford University

Press. https://doi.org/https://doi.org/10.1093/med:psych/9780195126709.001.0001

Denson, T. F., DeWall, C. N., \& Finkel, E. J. (2012). Self-control and aggression. Current Directions in Psychological Science, 21(1), 20-25. https://doi.org/10.1177/0963721411429451

DeWall, C. N., Finkel, E. J., \& Denson, T. F. (2011). Self-control inhibits aggression. Social and Personality Psychology Compass, 5(7), 458-472. https://doi.org/10.1111/j.1751-9004.2011.00363.x

Grandis, C. (2019). Hubungan Antara Dukungan Sosial Teman Sebaya Dengan Agresivitas Pada Remaja. http://repository.untag-sby.ac.id/id/eprint/2351

Hamama, L., \& Ronen-shenhav, A. (2012). Children and Youth Services Review Self-control , social support, and aggression among adolescents in divorced and two-parent families. Children and Youth Services Review, 34(5), 1042-1049. https://doi.org/10.1016/j.childyouth.2012.02.009

Hoberman, M. (1983). Life Change Stress ' $m$ a l. 99-125.

Hurlock, E. B. (2001). Developmental psychology : a life-span aproach. Tata McGraw-Hill Publishing.

Santrock, J. (1995). Life Span Development (Edisi Keli). Erlangga.

Luthfi. (2009). Psikologi Sosial. Lembaga Penelitian UIN.

Marsela, R. D., \& Supriatna, M. (2019). Kontrol Diri : Definisi dan Faktor. 3, 65-69.

Monks, F., Knoers, A., \& Hadito, S. R. (1999). Psikologi Perkembangan: Pengantar dalam berbagai bagiannya. Gadjah Mada University Press.

Õ, F. G. (2010). The effect of perceived social support on subjective well-being. 2, 3844-3849. https://doi.org/10.1016/j.sbspro.2010.03.602

Orpinas, P., \& Frankowski, R. (2001). of Early Adolescence A Self-Report Measure of.

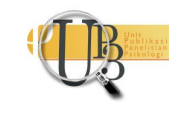


https://doi.org/10.1177/0272431601021001003

Pallant, J. (2010). SPSS Survival Manual: a Step Guide to Data Analysis Using Spss for Windows. Open University Press.

Praptiani, S. (2013). Pengaruh Kontrol Diri Terhadap Agresivitas Remaja dalam Menghadapi Konflik Sebaya dan Pemaknaan Gender. Jurnal Sains Dan Praktik Psikologi, I(1), 1-13. https://vdocuments.site/1340-3035-1-pbpdf.html

Prayogo, W. (2018). Hubungan Dukungan Sosial Orangtua Dan Religiusitas Dengan Perilaku Agresif. 6(4), 474-481.

Ratnasari, P. (2017). Hubungan Kontrol Diri dan Dukungan Sosial Keluarga dengan Agresivitas Siswa di SMK YP17 Pa. http://etheses.iainkediri.ac.id/id/eprint/280

Nurhalim, S. (2019). Teganya Anak Tendang Kepala Ibu Hanya Karena Uang Rp 10 Ribu. Detik.Com. https://news.detik.com/berita-jawa-timur/d-4675995/teganya-anak-tendang-kepala-ibuhanya-karena-uang-rp-10-ribu

Sumijah. (2016). PENGARUH DUKUNGAN SOSIAL DAN REGULASI DIRI TERHADAP AGRESIVITAS REMAJA DARI KELUARGA BROKEN HOME.

Suryanto, Ilham, N. A, Ike, H., Bagus. (2012). Pengantar Psikologi Sosial. Airlangga University Press.

Wills, T. A. (1985). Stress, Social Support, and the Buffering Hypothesis. 98(2).

Wulandari, M. S. (2016). Hubungan antara dukungan sosial dengan subjective well-being pada remaja penyandang disabilitas tunadaksa. Skripsi. Surabaya: Universitas Airlangga.

Zahrani \& Tri Kurniati Ambarini. (2019). Pelatihan Kontrol Diri untuk Menurunkan Perilaku Agresif Siswa Decreasing Student's Aggressive Behavior Through Self-control Training. 11(2), 104-113. 